\title{
Modulating the dose-rate differently affects the responsiveness of human epithelial prostate- and mesenchymal rhabdomyosarcoma-cancer cell line to radiation
}

Francesco Petragnano, Ilaria Pietrantoni, Valentina Di Nisio, Irene Fasciani, Andrea Del Fattore, Carlo Capalbo, Sara Cheleschi, Paolo Tini, Simone Orelli, Silvia Codenotti, Maria Antonietta Mazzei, Giuseppe D’Ermo, Gaetano Pannitteri, Mario Tombolini, Paola De Cesaris, Anna Riccioli, Antonio Filippini, Luisa Milazzo, Francesca Vulcano, Alessandro Fanzani, Roberto Maggio, Francesco Marampon \& Vincenzo Tombolini

To cite this article: Francesco Petragnano, Ilaria Pietrantoni, Valentina Di Nisio, Irene Fasciani, Andrea Del Fattore, Carlo Capalbo, Sara Cheleschi, Paolo Tini, Simone Orelli, Silvia Codenotti, Maria Antonietta Mazzei, Giuseppe D’Ermo, Gaetano Pannitteri, Mario Tombolini, Paola De Cesaris, Anna Riccioli, Antonio Filippini, Luisa Milazzo, Francesca Vulcano, Alessandro Fanzani, Roberto Maggio, Francesco Marampon \& Vincenzo Tombolini (2020): Modulating the doserate differently affects the responsiveness of human epithelial prostate- and mesenchymal rhabdomyosarcoma-cancer cell line to radiation, International Journal of Radiation Biology, DOI: 10.1080/09553002.2020.1739774

To link to this article: https://doi.org/10.1080/09553002.2020.1739774

Accepted author version posted online: 09 Mar 2020. Published online: 23 Mar 2020.

LII Article views: 30

Submit your article to this journal $\pi$

View Crossmark data $₫$ 


\title{
Modulating the dose-rate differently affects the responsiveness of human epithelial prostate- and mesenchymal rhabdomyosarcoma-cancer cell line to radiation
}

\author{
Francesco Petragnano ${ }^{a *}$, llaria Pietrantoni ${ }^{a *}$, Valentina Di Nisio ${ }^{b}$ (D), Irene Fasciani ${ }^{a}$, Andrea Del Fattore ${ }^{c}$, \\ Carlo Capalbo ${ }^{d}$, Sara Cheleschi ${ }^{\mathrm{e}}$, Paolo Tini ${ }^{\mathrm{f}, \mathrm{g}}$, Simone Orelli ${ }^{\mathrm{h}}$, Silvia Codenotti , Maria Antonietta Mazzei, \\ Giuseppe D'Ermok ${ }^{k}$, Gaetano Pannitteri', Mario Tombolinim ${ }^{m}$, Paola De Cesaris ${ }^{n}$, Anna Riccioli ${ }^{n}$, Antonio Filippini ${ }^{n}$, \\ Luisa Milazzo ${ }^{\circ}$, Francesca Vulcano ${ }^{\circ}$, Alessandro Fanzani ${ }^{i}$, Roberto Maggio ${ }^{\mathrm{a}}$, Francesco Marampon ${ }^{\mathrm{h} *}$, and \\ Vincenzo Tombolini ${ }^{\mathrm{h} *}$
}

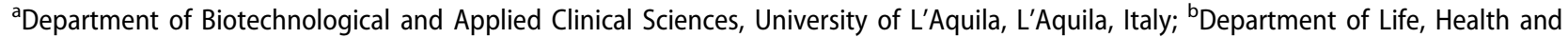
Environmental Sciences, University of L'Aquila, L'Aquila, Italy; 'Bone Physiopathology Unit Genetics and Rare Diseases Research Area, Bambino Gesù Children's Hospital, Rome, Italy; 'Department of Molecular Medicine, "Sapienza" University of Rome, Rome, Italy; ${ }^{\mathrm{e}}$ Department of Medicine, Surgery and Neuroscience, Rheumatology Unit, University of Siena, Policlinico Le Scotte, Siena, Italy; ${ }^{\mathrm{f} D e p a r t m e n t}$ of Biology, College of Science and Technology, Temple University, Philadelphia, PA, USA; ${ }^{9}$ Unit of Radiation Oncology, University Hospital of Siena, Siena, Italy; 'Department of Radiology, Radiotherapy, Oncology, Anatomopathology, "Sapienza" University of Rome, Rome, Italy; 'Department of Molecular and Translational Medicine, Division of Biotechnology, University of Brescia, Brescia, Italy; ${ }^{j}$ Unit of Medical Imaging, University Hospital of Siena, Siena, Italy; 'Department of Surgery "Pietro Valdoni", "Sapienza" University of Rome, Rome, Italy; 'Department of Cardiovascular, Respiratory, Nephrologic, Anaesthesiologic and Geriatric Sciences, Sapienza University, Rome, Italy; mepartment of Sense Organs, "Sapienza" University of Rome, Rome, Italy; "Department of Anatomy, Histology, Forensic Medicine and Orthopaedics, Section of Histology and Medical Embryology, "Sapienza" University, Rome, Italy; 'Department of Oncology and Molecular Medicine, Istituto Superiore di Sanità, Rome, Italy
\end{abstract}

\begin{abstract}
Purpose: Radiation therapy (RT), by using ionizing radiation (IR), destroys cancer cells inducing DNA damage. Despite several studies are continuously performed to identify the best curative dose of IR, the role of dose-rate, IR delivered per unit of time, on tumor control is still largely unknown. Materials and methods: Rhabdomyosarcoma (RMS) and prostate cancer (PCa) cell lines were irradiated with 2 or $10 \mathrm{~Gy}$ delivered at dose-rates of $1.5,2.5,5.5$ and $10.1 \mathrm{~Gy} / \mathrm{min}$. Cell-survival rate and cell cycle distribution were evaluated by clonogenic assays and flow cytometry, respectively. The production of reactive oxygen species (ROS) was detected by cytometry. Quantitative polymerase chain reaction assessed the expression of anti-oxidant-related factors including NRF2, SODs, CAT and GPx4 and miRNAs (miR-22, -126, -210, -375, -146a, -34a). Annexin V and caspase-8, -9 and -3 activity were assessed to characterize cell death. Senescence was determined by assessing $\beta$-galactosidase (SA- $\beta$-gal) activity. Immunoblotting was performed to assess the expression/ activation of: i) phosphorylated $\mathrm{H} 2 \mathrm{AX}(\gamma-\mathrm{H} 2 \mathrm{AX})$, markers of DNA double strand breaks (DSBs); ii) p19 $9^{\text {Kip1/Cip1 }}, \mathrm{p} 21^{\text {Waf1/Cip1 }}$ and p27 ${ }^{\text {Kip1/Cip1 }}$, senescence-related-markers; iii) p62, LC3-I and LC3-II, regulators of autophagy; iv) ATM, RAD51, DNA-PKcs, Ku70 and Ku80, mediators of DSBs repair.

Results: Low dose-rate (LDR) more efficiently induced apoptosis and senescence in RMS while high dose-rate (HDR) necrosis in PCa. This paralleled with a lower ability of LDR-RMS and HDR-PCa irradiated cells to activate DSBs repair. Modulating the dose rate did not differently affect the antioxidant ability of cancer cells.

Conclusion: The present results indicate that a stronger cytotoxic effect was induced by modulating the dose-rate in a cancer cell-dependent manner, this suggesting that choose the dose-rate based on the individual patient's tumor characteristics could be strategic for effective RT exposures.
\end{abstract}

\section{ARTICLE HISTORY}

Received 20 September 2019

Revised 25 January 2020

Accepted 7 February 2020

\section{KEYWORDS}

Rhabdomyosarcoma; prostate cancer; radiotherapy; dose rate; reactive oxygen species; double-strand DNA breaks

\section{Introduction}

More than half of cancer patients receive radiotherapy (RT) that finally contributes to $40 \%$ of curative oncological treatment. However, due to the intrinsic radioresistance of cancer cells, cure rates remain suboptimal for many cancer types (Baskar et al. 2012) indicating that new radiosensitizing strategies occur.
$\mathrm{RT}$, by using ionizing radiation (IR), products multiple types of lesions in DNA, including the most lethal DNA double-strand breaks (DSBs) that, if unrepaired, induce cell death. IR induces DSBs directly and indirectly by reactive oxygen species (ROS) generated through the IR-mediated water ionization and determining two-thirds of DSBs (Srinivas et al. 2018). Notably, cancer cells have developed a 
wide range of strategies that individually or collectively restrain the toxic action of IR with anti-oxidant activity and DSBs repair representing the main mechanisms responsible for radioresistance (Cortese et al. 2018).

In order to escape from ROS toxicity, cancer cells activate anti-oxidant response orchestrated by nuclear factor erythroid 2-related factor 2 (NRF2) signaling pathway, whose dysregulation has been largely demonstrated in various type of cancer (Ayers et al. 2015; Marampon et al. 2019; Rojo de la Vega et al. 2018). NRF2 controls the expression of several anti-oxidants proteins, such as superoxide dismutase 2 (SOD-2), catalase (CAT), glutathione peroxidase $4(\mathrm{GPx}-4)$ (Nguyen et al. 2009) and miRNAs, including miR-22, -34a, $-126,-210,-146 a,-375$, respectively shown to restrain oxidative stress injury by regulating the activity and or expression of Sirt 1 (Tang Q et al. 2018; Guo Y et al. 2017), ERBB receptor feedback inhibitor 1 (ERRFI1) (Wang W et al. 2019), iron-sulfur cluster assembly protein (ISCU) (Sun W et al. 2017), pro-inflammatory cytokine production (Qu X et al. 2019), connective tissue growth factor (CTGF) (Ou J et al. 2017). The cell fate decision following IR exposure depends on the amount and quality of DSBs. Low levels and/or potentially easily repairable DSBs trigger DNA damage response (DDR) mechanisms, which induce reversible cell cycle growth arrest and allow cells to repair DNA before returning to the proliferative pool (Morgan and Lawrence 2015). This a very complex process that provides the activation of DDR and then of two major DNA repair pathways: the more error-prone non-homologous end joining (NHEJ) and the more accurate homologous recombination (HR), respectively occurring in the $G_{2} / M$ and $S$ phase of the cell cycle (Hufnagl et al. 2015). Cancer cells, by over-activating DSB repair mechanisms, can overcome IR-associated toxicity. Furthermore, when NHEJ signaling is recruited, cancer cell can accumulate chromosomal aberrations responsible for the selection of more radioresistant cells (Sishc and Davis 2017). Thus, any potential strategies able to amplify ROS production, prevent the anti-oxidant and pro-DSBs repair abilities of cancer cells could play a key role in improving the therapeutic efficiency of IR (Ciccarese and Ciminale 2017).

Recent developments in RT, both in technical advances and in clinical approaches, permit to deliver high dose of IR in less time (Sutera et al. 2019) even though the role of the dose-rate, radiation delivered per unit of time, on tumor control is largely unknown and the development of linear accelerator able of ultra-high-dose-rates has newly prompted the discussion. A wide range of dose-rates has been used in radiobiology or RT and it is generally considered that the cell-killing effect of IR decreases continuously as the dose-rate decreases, due to the ability of cancer cells to repair sub-lethal DSBs during the irradiation (Hall 1972; Ling et al. 2010). On this regards, other evidences show that respect high-dose-rate (HDR), lowdose-rate (LDR) can more easily kill cancer cells (Matsuya et al. 2018; Steel et al. 1987; Terashima et al. 2017; Williams et al. 2008). Thus, characterizing if there is a 'more efficient' dose-rate for any tumor type should be investigated also because often patients with different tumors are treated with the same dose-rate while the same tumor type is treated with different dose-rate between different radiotherapy department.

This study describes the in vitro activity of modulating dose-rate on epithelial-derived castration-resistant prostate (PCa) and mesenchimal-derived embryonal (ERMS) and alveolar (ARMS) rhabdomyosarcoma (RMS) cancer cell lines, which are used as models of highly radioresistant tumors (Gravina et al. 2014; Ciccarelli et al. 2016; Gravina et al. 2016; Marampon et al. 2016a, 2016b; Ciccarelli et al. 2018). Herein we found that dose-rate modulation differently affected the surviving fraction of cancer cells by interfering with their ability to detoxify from IR-induced ROS accumulation and to repair DSBs. Taken together, our data suggest that modifying the dose-rate in a cancer-typedependent-manner can represent a key strategy to enhance RT efficacy against tumor cells.

\section{Material and methods}

\subsection{Cell culture}

Alveolar rhabdomyosarcoma RH30 cell line was obtained from DSMZ (Braunschweig, Germany). Embryonal rhabdomyosarcoma $\mathrm{RD}$, androgen independent androgen-receptor positive DU145 or negative PC3 prostate cancer cell lines were obtained from American Type Culture Collection. Cell lines were maintained as previously described (Marampon et al. 2011; Gravina et al. 2013).

\subsection{Irradiation and colony formation assay}

Irradiation was carried out using an ONCOR Impression Linear Accelerator (Siemens Medical Solutions USA, Inc, Concord, CA) at a dose rate of 2 or $10 \mathrm{~Gy}(1.5,2.5,5.5$ and $10.1 \mathrm{~Gy} / \mathrm{min})$. RMS and Pca cells $\left(3 \times 10^{5}\right)$ were incubated in six-well cell culture plates overnight to allow cell adhesion and then irradiated. After $4 \mathrm{~h}$ incubation at $37^{\circ} \mathrm{C}, 5 \% \mathrm{CO} 2$, $2 \times 10^{2}$ cells/well were seeded in 24-well plates in triplicate. Medium was replaced every 3 days and after 12 days, colonies were stained with $0.1 \%$ crystal violet for $5 \mathrm{~min}$ at room temperature (RT). Colonies were photographed, and then crystal violet was solubilized in 30\% acetic acid in water for $15 \mathrm{~min}$ at RT; absorbance was measured by using the Biochrom Libra S22 UV/VIS spectrophotometer (Biochrom, Berlin, DE) at wavelength of $595 \mathrm{~nm} ; 30 \%$ acetic acid in water was used as the blank (Marampon et al. 2016a, 2016b). Colony formation capacity in IR-treated cells was calculated in comparison to non-irradiated cells, arbitrarily set to 1 . The results were plotted as means $\pm S D$ of three separate experiments having three determinations per assay for each experimental condition.

\subsection{Cell cycle analysis by flow cytometry}

For the cell cycle analysis, cancer cells $\left(3 \times 10^{5}\right)$ were incubated in six-well cell culture plates overnight to allow cell 
adhesion. Cells were irradiated or not and then incubated for additional $24 \mathrm{~h}$ at $37^{\circ} \mathrm{C}$. Samples were stained with Propidium Iodide (PI) solution and subjected to flow cytometry by using a BD FACSCalibur (BD Biosciences, Franklin Lakes, NJ), as previously described (Marampon et al. 2014). Flow cytometry data were quantified by using the ModFit LT 3.0 program (Verity Software House). The results were plotted as means $\pm \mathrm{SD}$ of three separate experiments having three determinations per assay for each experimental condition.

\subsection{Apoptosis, caspases activation status and SA- $\beta$-gal quantification}

Approximately $2 \times 10^{5}$ cells were stained with Annexin V and 7-Amino-Actinomycin (7-AAD) for $15 \mathrm{~min}$ at RT in the dark (ab214663, Abcam, Cambridge, UK). Fluorescence intensities of treated samples and controls were analyzed by flow cytometry by using the BD Cell Quest Pro software. Experiments were performed at least twice. Caspase-Glo ${ }^{\circledR} 3$ (G8090), 8 (G8200) and 9 (G8210) assays from Promega were used to measure the caspase activity. Detection of SA$\beta$-gal activity was assessed by using Cellular Senescence Assay Kit from Cells Biolabs, INC. All assays were performed according to the manufacturer's instructions. The results were plotted as means $\pm S D$ of three separate experiments having three determinations per assay for each experimental condition.

\subsection{Protein extraction and Western blotting}

Total protein extracts and Western blotting assays were performed as previously described (De Palma et al. 2017; Gravina et al. 2017), by using the following primary antibodies: Cyclindependent kinase inhibitor 1 or $\mathrm{p} 21^{\mathrm{WAF} 1},(\mathrm{C}-19,1: 250)$, Cyclin-dependent kinase inhibitor $1 \mathrm{~B}$ or p27 ${ }^{\mathrm{KIP} 1}$, (F-8, 1:250), Sequestosome-1 or p62 (D-3, 1:250), H2A histone family member X or H2AX (C-20, 1:250), phosphorylated-Ataxia-telangiectasia mutated or ATM-po4 (10H11.E12, 1:250), Ataxiatelangiectasia mutated or ATM (G-12, 1:250), Rad51 (H-92, 1:250), DNA-dependent protein kinase, catalytic subunit or DNA-PKCs (G-4, 1:250), Ku70 (E5, 1:250) (Santa Cruz Biotechnology, Dallas, TX, USA), phosphorylated-H2A histone family member $\mathrm{X}$ or $\gamma$-H2AX (Ser139, 1:1000) (2577) (Cell Signaling Technology, Danvers, MA, USA), phosphorylatedDNA-PKCs (phosphor S2056, 1:1000) (as18192), Ku80 (5C5, 1:1000) (ab119935) (Abcam, Cambridge, UK), LC3-I/II (ABC929, 1:1000) (Sigma-Aldrich, St. Luis, MO, USA). Antibody against $\alpha$-Tubulin (TU-02, 1:5000) (Santa Cruz Biotechnology, Dallas, TX, USA) was used as a loading control. Appropriate horseradish peroxidase (HRP)-conjugated secondary antibodies (Santa Cruz Biotechnology, Dallas, TX, USA) were used for $1 \mathrm{~h}$ at room temperature. Three separate experiments having three determinations per assay for each experimental conditions, were performed.
Table 1. List of the primers used for the RT-PCR.

\begin{tabular}{lc}
\hline miRNA Genes & Cat. No. (Qiagen) \\
\hline miR-22 & MS00003220 \\
miR-126 & MS00003430 \\
miR-210 & MS00003801 \\
miR-375 & MS00031829 \\
miR-146a & MS00003535 \\
miR-34a & MS00003318 \\
Target genes & \\
SOD-2 & QT01008693 \\
CAT & QT00079674 \\
GPx4 & QT00067165 \\
NRF2 & QT00027384 \\
ACTB & QT00095431 \\
\hline miRNA: microRNA; SOD-2: superoxide dismutase 2; CAT: cata- \\
lase; GPx4: glutathione peroxidase 4; NRF2: nuclear factor \\
erythroid 2 like 2; ACTB: Actin Beta.
\end{tabular}

\section{6. $R N A$ extraction and quantitative real time $P C R$ ( $q-P C R)$}

Cells were grown and maintained in 6-well dishes at a starting density of $3 \times 10^{5}$ cells/well until they became $60-70 \%$ confluent. Then, cells were irradiated. Total RNA, including miRNA, was extracted by using TriPure Isolation Reagent (Euroclone, Milan, Italy) according to the manufacturer's instructions and was stored at $-80{ }^{\circ} \mathrm{C}$. The concentration, purity and integrity of RNA were evaluated by measuring the OD at $260 \mathrm{~nm}$ and the $260 / 280$ and $260 / 230$ ratios with Nanodrop-1000 (Celbio, Milan, Italy). The quality of RNA was also verified by electrophoresis on agarose gel (FlashGel System, Lonza, Rockland, ME, USA). Reverse transcription for SOD-2, CAT, GPx-4 genes and miR-22, -126, -210, $-146 \mathrm{a},-34 \mathrm{a},-375$ miRNAs was carried out by the cDNA miScript PCR Reverse Transcription (Qiagen, Hilden, Germany), while the same procedure for target genes by QuantiTect Reverse Transcription Kit (Qiagen, Germany), according to the manufacturer's instructions. MiRNA and target genes were examined by real-time PCR by using miScript SYBR Green (Qiagen, Hilden, Germany) and QuantiFast SYBR Green PCR (Qiagen, Hilden, Germany) kits, respectively (Cheleschi et al. 2018). A list of the used primers is reported in Table 1. Three separate experiments having three determinations per assay for each experimental conditions, were performed.

\subsection{Mitochondrial superoxide anion $\left(\bullet \mathrm{O2}^{-}\right)$production}

Cancer cells $\left(3 \times 10^{5}\right)$ were incubated in six-well cell culture plates overnight to allow cell adhesion and then irradiated or not. Immediately and $12 \mathrm{~h}$ after radiation exposure, flow cytometry analysis was performed. Medium was discarded, and cells were incubated in Hank's Balanced Salt Solution (HBSS) (Sigma-Aldrich, Milan, Italy) and MitoSOX Red (Thermo Fisher Scientific, Milan, Italy) for 15 minutes at $37^{\circ} \mathrm{C}$ in dark, to evaluate mitochondrial superoxide anion $\left(\bullet \mathrm{O} 2^{-}\right)$production. MitoSOX Red was dissolved in DMSO at the final concentration of $5 \mu \mathrm{M}$. Cells were then harvested by trypsin, collected into cytometry tubes and centrifuged at $1500 \mathrm{rpm}$ for 10 minutes. Besides, $1 \times 10^{4}$ cells per assay were resuspended in saline solution and analyzed by flow 
cytometry. Data were analyzed with CellQuest software (Becton Dickinson) and results were represented as median of fluorescence (AU) (Cheleschi et al. 2017). The results were plotted as means $\pm \mathrm{SD}$ of three separate experiments having three determinations per assay for each experimental condition.

\subsection{Statistical analysis}

The results were expressed as the mean $\pm \mathrm{SD}$ of three independent experiments, each performed in triplicate. Data normal distribution was confirmed by Shapiro-Wilk, D'Agostino \& Pearson and Kolmogorov-Smirnov tests. Real-time PCR experiments were evaluated by one-way (ANOVA) with a Tukey's post hoc test using $2-\Delta \Delta$ Ct values for each sample. Flow cytometry data were analyzed by ANOVA with a Bonferroni post hoc test. All analyses were performed using the SAS System (SAS Institute Inc., Cary, NC) and GraphPad Prism 6.1. A statistically significant effect was indicated by a $p$ value $<.05$.

\section{Results}

\subsection{LDR on RMS and HDR on PCa improve the ability of IR to induce DSBs and related toxicity, independently from the total dose delivered}

The effects of modulating dose-rate on responsiveness to IR of cancer cells were assessed by clonogenic assay. To this purpose RMS (RD and RH30) and PCa (PC3 and DU145) cell lines were irradiated with a dose of $2 \mathrm{~Gy}$ or $10 \mathrm{~Gy}$, delivered at the dose-rate of $1.5,2.5,5.5$ and $10.1 \mathrm{~Gy} / \mathrm{min}$. Independently from the total dose delivered, IR more efficiently reduced the surviving fraction at the dose-rates of $1.5-2.5 \mathrm{~Gy} / \mathrm{min}$ on RMS (Figure $1(\mathrm{~A}), \mathrm{RD}$ and $\mathrm{RH} 30,1.5$ and $2.5 \mathrm{~Gy} / \mathrm{min}$ vs. 5.5 and $10.1 \mathrm{~Gy} / \mathrm{min}$.) and $5.5-10.1 \mathrm{~Gy} /$ min on PCa RMS (Figure 1(A), PC3 and DU145, 1.5 and $2.5 \mathrm{~Gy} / \mathrm{min}$ vs. 5.5 and $10.1 \mathrm{~Gy} / \mathrm{min}$ ). Next experiments were then performed by treating cancer cells with $2 \mathrm{~Gy}$ at the dose-rate of $1.5 \mathrm{~Gy} / \mathrm{min}$ (LDR) or $10.1 \mathrm{~Gy} / \mathrm{min}$ (HDR). The ability of modulating the dose-rate on inducing DSBs was investigated by assessing the amount of phosphorylated/activated form of H2AX $(\gamma-\mathrm{H} 2 \mathrm{AX})$ (Kuo and Yang 2008). As shown in Figure 1(B), $1.5 \mathrm{~Gy} / \mathrm{min}$ on RMS (Figure 1(A), RD and $\mathrm{RH} 30,1.5 \mathrm{~Gy} / \mathrm{min}$ vs. $10.1 \mathrm{~Gy} / \mathrm{min}$.) and $10.1 \mathrm{~Gy} / \mathrm{min}$ on PCa (Figure 1(A), PC3 and DU145, $1.5 \mathrm{~Gy} / \mathrm{min}$ vs. $10.1 \mathrm{~Gy} /$ min.), more rapidly $(4 \mathrm{~h})$, efficiently and persistently $(12 \mathrm{~h})$ upregulated $\gamma$-H2AX. Cell cycle growth arrest occurred after IR and, although controversial, this is perhaps the most important determinant of IR sensitivity, with cells being most radiosensitive in the $G_{2} / M$ phase, less sensitive in the $G_{1}$ phase, and least sensitive during the latter part of the $S$ phase (Hufnagl et al. 2015). Investigating the effects of modulating the dose-rate on the cell cycle distribution, we found that irradiated cells showed growth arrest in $G_{2} / M$ phase without any significant difference between the dose-rate used (Figure 1(C)).

\section{2. $L D R$ in RMS and HDR in PCa improve toxicity of conventional dose fractionation by progressively inducing $G_{2} / M$ cell cycle growth arrest}

According to the radiobiological concept of redistribution, fractionating the dose can synchronize tumor cells in the $\mathrm{G}_{2} / \mathrm{M}$ phase of the cell cycle, known to be the most radiosensitive, thus promoting a greater toxicity of subsequent fractions (Hahnfeldt and Hlatky 1996). The effects of modulating the dose-rate on daily treated cells, $2 \mathrm{~Gy}$ for 5 consecutive days, were investigated on surviving fraction and cell cycle distribution by flow cytometry, performed after the first, third and fifth day of treatment (Figure 2(A)). 1.5, Gy/ min. on RMS and $10.1 \mathrm{~Gy} / \mathrm{min}$. on PCa more efficiently reduced the surviving fraction and this become evident starting after the $2^{\text {th }}$ fraction (Figure 2(A), RMS and PCa, $1.5 \mathrm{~Gy} / \mathrm{min}$. vs. $10.1 \mathrm{~Gy} / \mathrm{min}$.). Flow cytometry shows that both 1.5 and $10.1 \mathrm{~Gy} / \mathrm{min}$. progressively increased the percentage of cancer cell arrested in the $\mathrm{G}_{2} / \mathrm{M}$ cell cycle phase (Figure 2(B), \% of cells in $\mathrm{G}_{2} / \mathrm{M}, 5$ fractions $>4>3>$ $2>1)$. However, it occurred more efficiently on LDR-irradiated RMS and HDR-irradiated PCa (Figure 2(A), RMS and $\mathrm{PCa}, \%$ of cells in $\mathrm{G}_{2} / \mathrm{M}, 5$ fractions $1.5 \mathrm{~Gy} / \mathrm{min}$. vs. $10.1 \mathrm{~Gy} / \mathrm{min}$.).

\section{3. $L D R$ in RMS and HDR in PCa differently induces apoptosis, senescence and modulates the autophagic flux}

Apoptosis, necrosis, cellular senescence and autophagy are key responses of an irradiated cell (Eriksson and Stigbrand 2010). The ability of modulating the dose-rate to induce these biological events was investigated on RMS and $\mathrm{PCa}$ treated with a single dose of $2 \mathrm{~Gy}$ at the dose-rate of $1.5 \mathrm{~Gy} /$ min. and $10.1 \mathrm{~Gy} / \mathrm{min}$. Annexin V/7-amino-actinomycin staining was performed in order to discriminate apoptosis from necrosis (Zimmermann and Meyer 2011). As shown in Figure 3(A), IR induced apoptosis in RMS and necrosis in $\mathrm{PCa}$, more efficiently in RMS-LDR and PCa-HDR-treated cells, respectively (Figure 3(A), RMS and $\mathrm{PCa}, 1.5 \mathrm{~Gy} / \mathrm{min}$. vs. $10.1 \mathrm{~Gy} / \mathrm{min}$ ). No differences between LDR and HDR were described about the ability of IR to activate caspase-9 and -3 in RH30 and PCa cell lines and (Figure 3(B), RH30, PC3 and DU145) also caspase-8 in RD cells (Figure 3(B), $\mathrm{RD})$. The expression levels of p62 and LC3-II respectively down- and up-regulated during autophagy, (Bjørkøy et al. 2009; Kabeya et al. 2000) were investigated. On RMS cells, LDR increased the expression of p62 (Figure 4, RD and RH30, $1.5 \mathrm{~Gy} / \mathrm{min}$. vs. $10.1 \mathrm{~Gy} / \mathrm{min}$.) and reduced the expression levels of LC3-II in RH30 (Figure 4, RH30, $1.5 \mathrm{~Gy} / \mathrm{min}$. vs. $10.1 \mathrm{~Gy} / \mathrm{min}$.) but not in $\mathrm{RD}$ cells (Figure $4, \mathrm{RD}, 1.5 \mathrm{~Gy} /$ min. vs. $10.1 \mathrm{~Gy} / \mathrm{min})$. No modulation of p62, LC3-I and LC3-II were described in PCa cells (Figure 4, PCa). IR increased the senescence-associated $\beta$-galactosidase (SA$\beta$-gal) activity more efficiently at the LDR in RMS (Figure 5(A), RMS, $1.5 \mathrm{~Gy} / \mathrm{min}$. vs. $10.1 \mathrm{~Gy} / \mathrm{min}$.), whilst no statistically significant differences between LDR- and HDR-treated cells were described on PCa cells (Figure 5(A), PCa, 1.5 Gy/

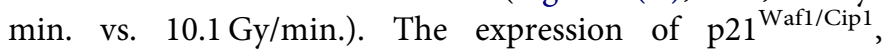



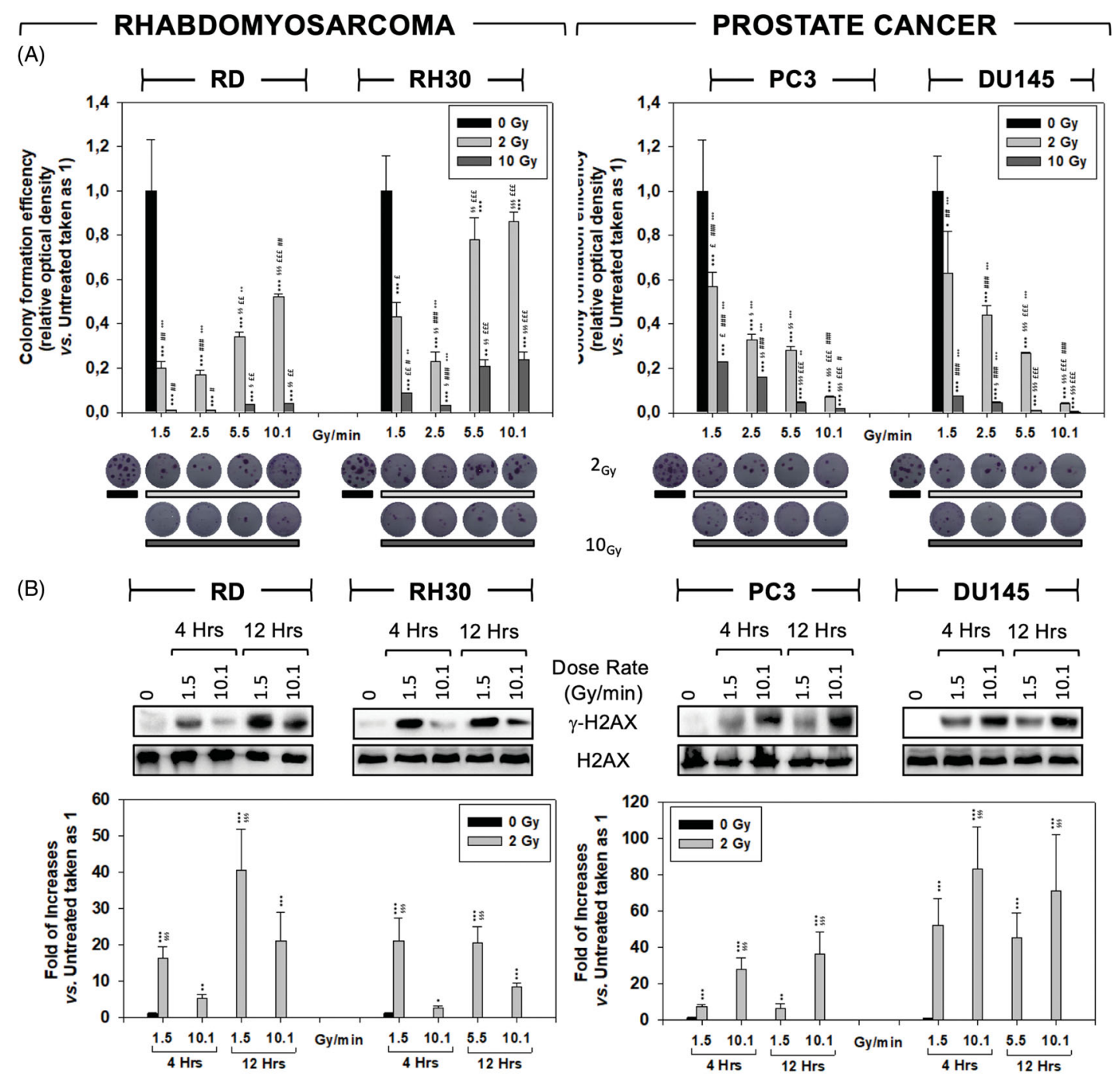

(C)
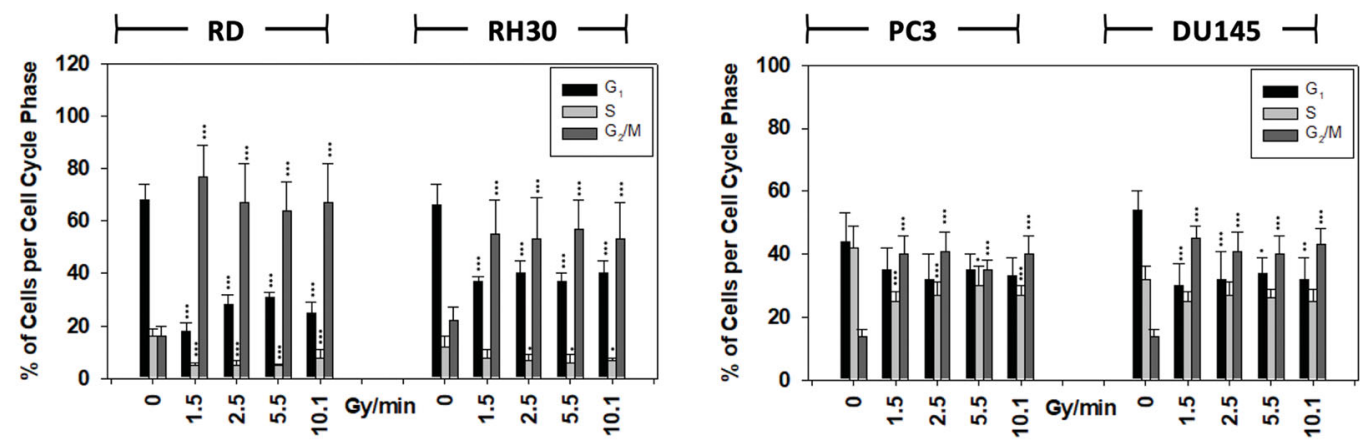

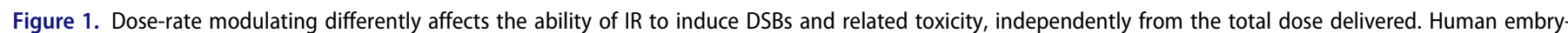

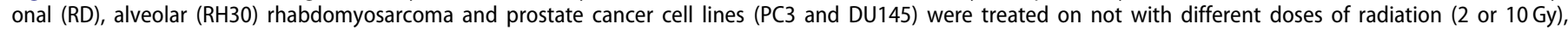

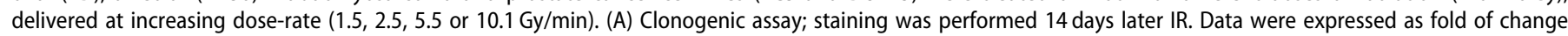

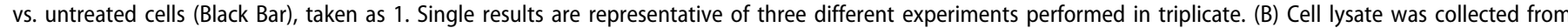

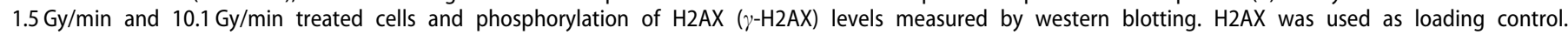

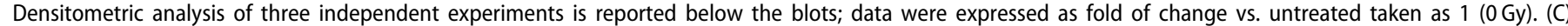

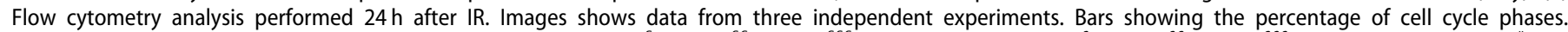

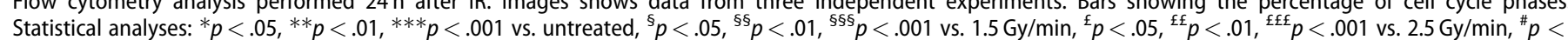
$.05,{ }^{\# \#} p<.01,{ }^{\# \# \#} p<.001$ vs. $5.5 \mathrm{~Gy} / \mathrm{min},{ }^{\circ} p<.05,{ }^{\circ 0} p<.01,{ }^{\circ 00} p<.001$ vs. $10.1 \mathrm{~Gy} / \mathrm{min}$.

$\mathrm{p} 27^{\mathrm{Kip} 1 / \mathrm{Cip} 1}$ and $\mathrm{p} 19^{\mathrm{Kip} 1 / \mathrm{Cip} 1}$, the most widely used biomarker for senescent and aging cells (Dimri et al. 1995), resulted significantly increased both in RMS and PCa cells (Figure 5(B), RMS and PCa). On RD cells, HDR more efficiently upregulated the expression of $\mathrm{p} 21^{\text {Waf1/Cip1 }}$ and p2 $7^{\text {Kip1/Cip1 }}$ whilst LDR modulated p19 ${ }^{\text {Kip1/Cip1 }}$ levels (Figure
5(B), RD, p21 ${ }^{\text {Wafl/Cip } 1}, \mathrm{p} 27^{\text {Kip1/Cip1 }}$ and $\mathrm{p} 19^{\mathrm{Kip} 1 / \mathrm{Cip} 1}, 1.5 \mathrm{~Gy} /$ min. vs. $10.1 \mathrm{~Gy} / \mathrm{min}$.). On RH30 cells, LDR more efficiently upregulated the expression of $\mathrm{p} 19^{\mathrm{Kip} 1 / \mathrm{Cip} 1}$ (Figure 5(B), RH30, p19 ${ }^{\text {Kip1/Cip1 } 1}, 1.5 \mathrm{~Gy} / \mathrm{min}$. vs. $10.1 \mathrm{~Gy} / \mathrm{min}$ ), whilst no difference was described about the levels of $\mathrm{p} 21^{\text {Waf1/Cip } 1}$ and $\mathrm{p} 27^{\mathrm{Kip} 1 / \mathrm{Cip} 1}$ (Figure 5(B), RH30, p21 $1^{\text {Wafl/Cip1 }}$ and $\mathrm{p} 27^{\mathrm{Kip} 1 /}$ 

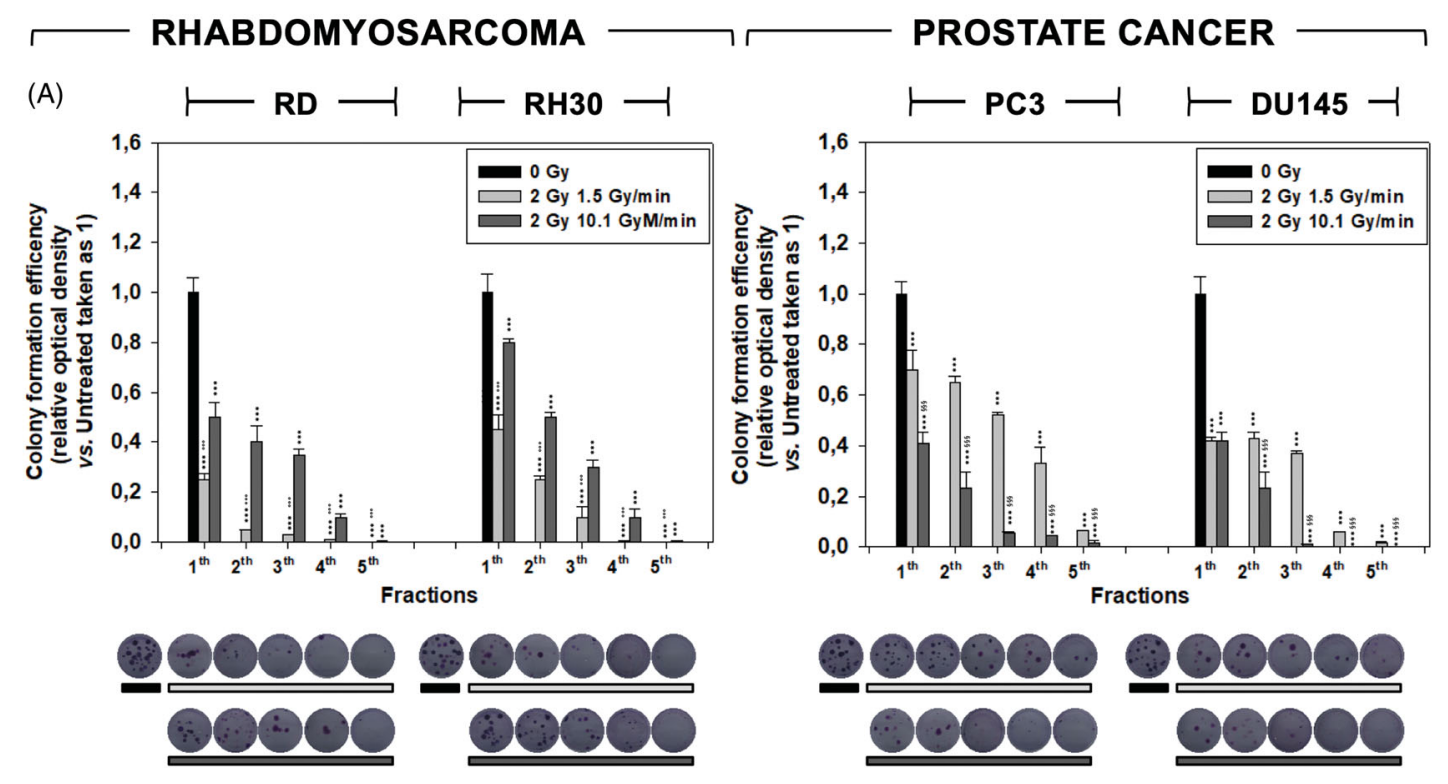

(B)
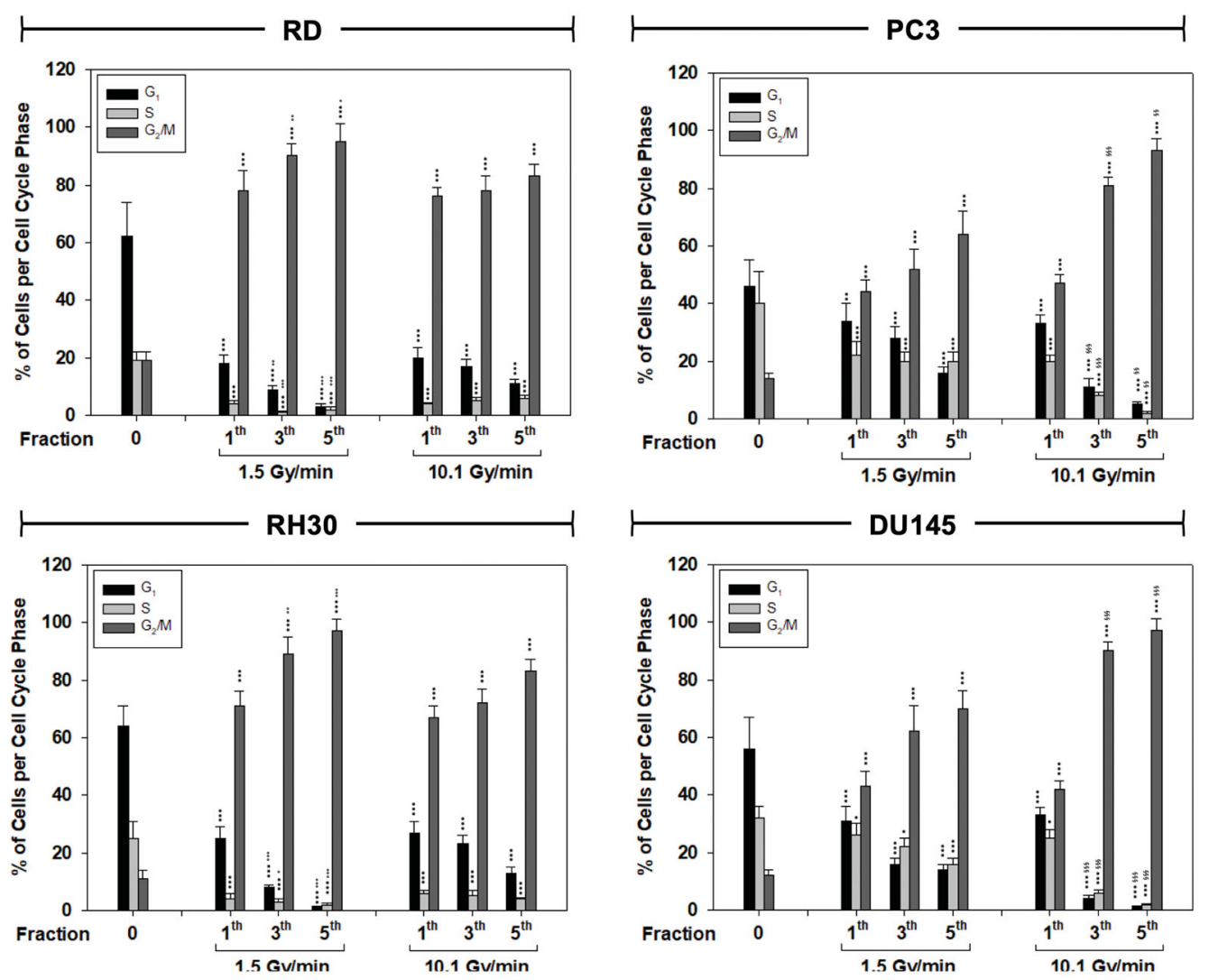

Figure 2. Dose-rate modulation affects the toxicity of conventional dose fractionation by progressively inducing $\mathrm{G}_{2} / \mathrm{M}$ cell cycle growth arrest. Human embryonal (RD), alveolar (RH30) rhabdomyosarcoma and prostate cancer cell lines (PC3 and DU145) were treated on not with a dose of 2 Gy of radiation, delivered at the dose-rate of 1.5 or $10.1 \mathrm{~Gy} / \mathrm{min}$. (A) Clonogenic assay; staining was performed 14 days later IR. Data were expressed as fold of change vs. untreated cells (Black Bar), taken as 1 . Single results are representative of three different experiments performed in triplicate. (B) Flow cytometry analysis performed $24 \mathrm{~h}$ after IR. Images shows data from three independent experiments. Bars showing the percentage of cell cycle phases. Statistical analyses: ${ }^{*} p<.05,{ }^{* *} p<.01, * * * p<.001$ vs. untreated,

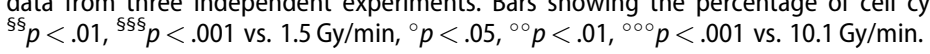

Cip1 $1.5 \mathrm{~Gy} / \mathrm{min}$. vs. $10.1 \mathrm{~Gy} / \mathrm{min})$. HDR more efficiently upregulated the expression of $\mathrm{p} 19^{\mathrm{Kip} 1 / \mathrm{Cip} 1}$ both in PC3 and DU145 cells (Figure 5(B), PC3 and DU145, p19 ${ }^{\text {Kip1/Cip1, }}$ $1.5 \mathrm{~Gy} / \mathrm{min}$. vs. $10.1 \mathrm{~Gy} / \mathrm{min})$, whilst no differences were described about the expression of $21^{\text {Wafl/Cip1 }}$ (Figure $5(\mathrm{~B})$, PC3 and DU145, p21 $1^{\text {Waf1/Cip1 }}$ and p27 ${ }^{\text {Kip1/Cip1 }}, 1.5 \mathrm{~Gy} / \mathrm{min}$. vs. $10.1 \mathrm{~Gy} / \mathrm{min}$.).

\subsection{Modulating the dose-rate does not change the} ability of IR to induces ROS accumulation but differently affect the anti-oxidant response of RMS and PCa cells

The effects of dose-rate modulation on ROS production and the expression of NRF2, SOD-2, CAT, GPx-4 genes 
RHABDOMYOSARCOMA

(A)
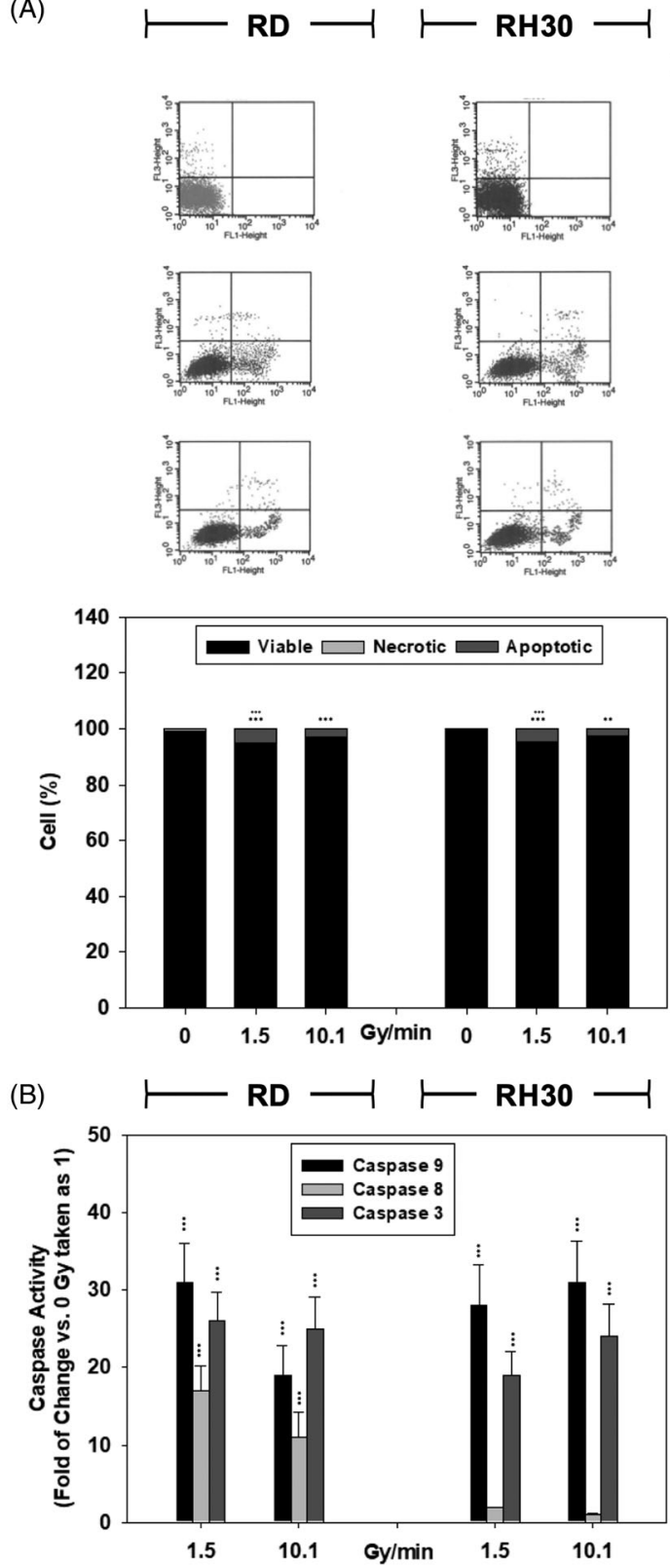

PROSTATE CANCER

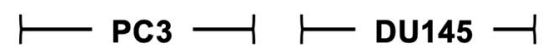

Dose Rate

(Gy/min)

0
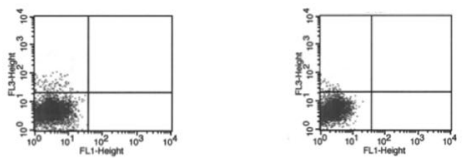

1.5
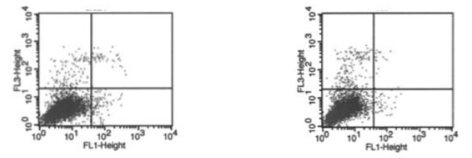

10.1
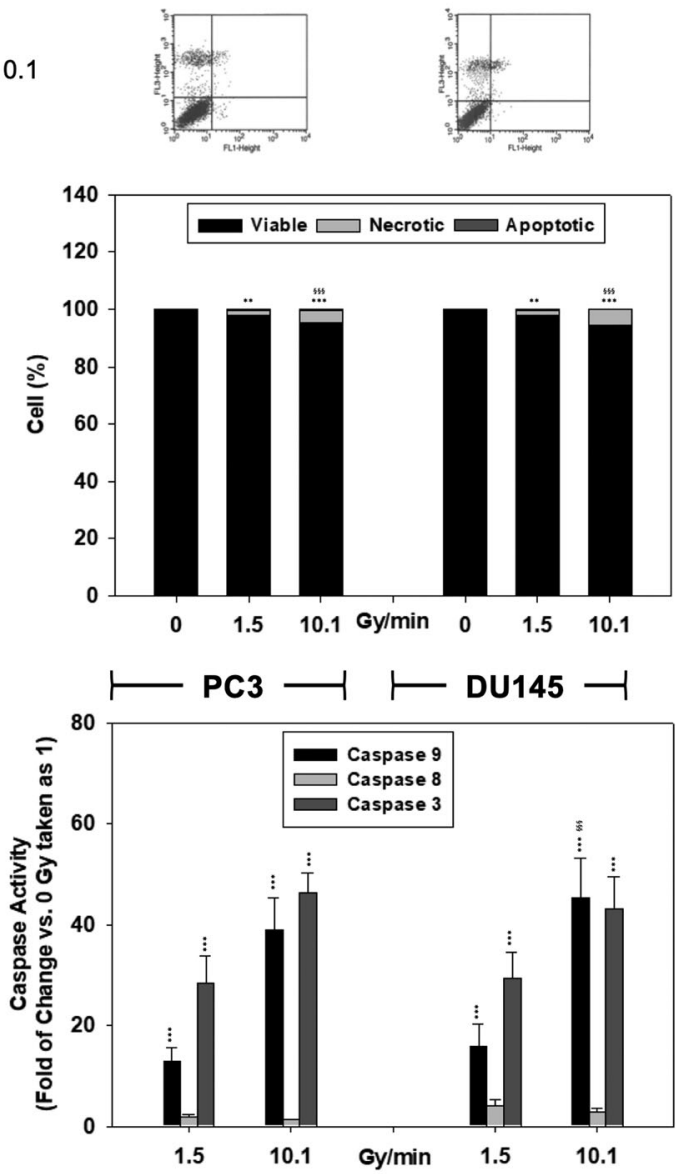

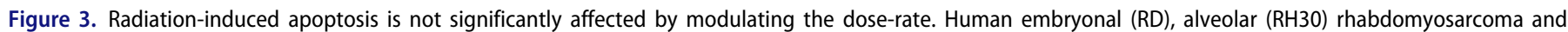

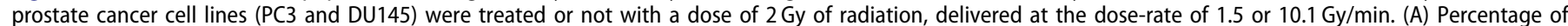

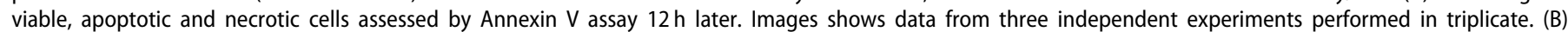

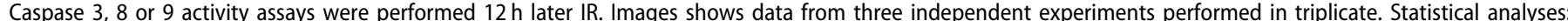
${ }^{*} p p<.01,{ }^{* * *} p<.001$ vs. untreated, ${ }^{\S \S \S} p<.001$ vs. $1.5 \mathrm{~Gy} / \mathrm{min},{ }^{\circ 00} p<.001$ vs. $10.1 \mathrm{~Gy} / \mathrm{min}$.

and $\operatorname{miR}-22,-126,-210,-146 a,-34 a,-375$ miRNAs, were assessed on RMS and PCa cells treated with a single dose of $2 \mathrm{~Gy}$ at the dose-rate of $1.5 \mathrm{~Gy} / \mathrm{min}$. and $10.1 \mathrm{~Gy} / \mathrm{min}$. No differences between LDR and HDR were described on ROS production immediately and $24 \mathrm{~h}$ after RT (Figure 6(A), RMS and PCa, $1.5 \mathrm{~Gy} / \mathrm{min}$. vs. $10.1 \mathrm{~Gy} / \mathrm{min}$.). q-PCR, performed on mRNA and miRNAs collected 2 and $24 \mathrm{~h}$ after RT, shows that NRF2, SOD-2, CAT and GPx-4 expression was significantly and persistently increased in RMS without differences between the dose rates used (Figure 6(B), RD and RH30, $1.5 \mathrm{~Gy} / \mathrm{min}$. vs. $10.1 \mathrm{~Gy} / \mathrm{min}$.). On PCa cells, the expression of NRF2 was significantly and persistently increased, whilst SOD-2, CAT and GPx-4 levels were downregulated both in PC3 and DU145 without differences between the dose rates used (Figure 6(B), PC3 and DU145, $1.5 \mathrm{~Gy} / \mathrm{min}$. vs. $10.1 \mathrm{~Gy} / \mathrm{min}$.). As concerning miRNAs, we found that HDR more efficiently increased the expression of miR-146a, miR-34a, miR-22, miR-126 and miR-210 in RD (Figure 6(C), RD, $1.5 \mathrm{~Gy} /$ min. vs. $10.1 \mathrm{~Gy} / \mathrm{min}$ ), miR-34a, miR-22, miR-126, miR210 and miR-375 in RH30 (Figure 6(C), RH30, $1.5 \mathrm{~Gy} /$ min. vs. $10.1 \mathrm{~Gy} / \mathrm{min}$ ), $\mathrm{miR}-375$ in PC3 (Figure 6(C), PC3, $1.5 \mathrm{~Gy} / \mathrm{min}$. vs. $10.1 \mathrm{~Gy} / \mathrm{min}$ ) and $\mathrm{miR}-210$ in DU145 cells (Figure 6(C), DU145, $1.5 \mathrm{~Gy} / \mathrm{min}$. vs. $10.1 \mathrm{~Gy} / \mathrm{min}$ ). 

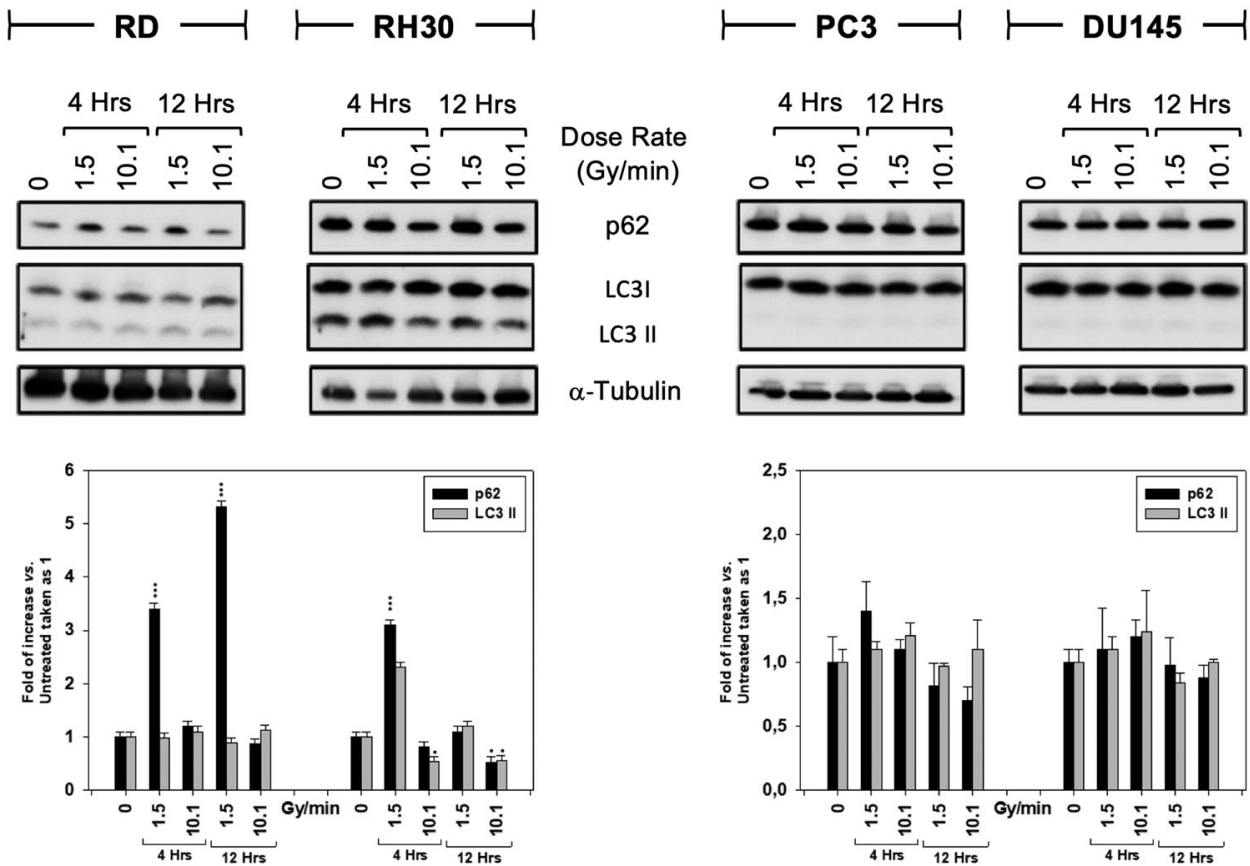

Figure 4. Dose-rate modulation differently induces autophagy. Human embryonal (RD), alveolar (RH30) rhabdomyosarcoma and prostate cancer cell lines (PC3 and DU145) were treated on not with a dose of $2 \mathrm{~Gy}$ of radiation, delivered at the dose-rate of 1.5 or $10.1 \mathrm{~Gy} / \mathrm{min}$. Cell lysate was collected 4 and $12 \mathrm{~h}$ after IR; p62, LC3I and LC3-II levels measured by western blotting. Images show representative western blots of three independent experiments; $\alpha$-Tubulin was used as loading control. Densitometric analysis of three independent experiments is reported below the blots; data were expressed as fold of change vs. untreated taken as 1 ( $0 \mathrm{~Gy}$ ). Statistical analyses: $* p<.05, * * * p<.001$ vs. untreated.

\subsection{Dose-rate modulation differently affects the activation of DNA DSB mechanisms in RMS and PCa radioresistance}

The activation status of the homologous recombination (HR) and nonhomologous end joining (NHEJ) pathways, whose aberrant activation participates in determining radioresistance (Morgan and Lawrence 2015), was investigated by assessing the phosphorylation and/or expression levels of ATM and RAD51 (NHEJ) and DNA-PKCs, Ku70 and Ku80 (HR) in western blot experiments. On RD cells line, HDR more efficiently increased the phosphorylation/activation status of ATM and DNA-PKcs (Figure 7, RMS, $1.5 \mathrm{~Gy} / \mathrm{min}$. vs. $10.1 \mathrm{~Gy} / \mathrm{min}$.) whilst no differences were described about the IR-induced up-regulation of Ku80 (Figure 7, RMS, $1.5 \mathrm{~Gy} / \mathrm{min}$. vs. $10.1 \mathrm{~Gy} / \mathrm{min}$.). On RH30 cells line, the phosphorylation/activation status of ATM and DNA-PKcs was more efficiently increased by HDR and LDR, respectively (Figure 7, RMS, $1.5 \mathrm{~Gy} / \mathrm{min}$. vs. $10.1 \mathrm{~Gy} / \mathrm{min}$.) whilst HDR more efficiently induced up-regulation of Ku80 (Figure 7, RMS, $1.5 \mathrm{~Gy} / \mathrm{min}$. vs. $10.1 \mathrm{~Gy} / \mathrm{min}$.). On PCa cells lines LDR more efficiently increased the phosphorylation/activation status of ATM and DNA-PKcs (Figure 7, PCa, $1.5 \mathrm{~Gy} / \mathrm{min}$. vs. $10.1 \mathrm{~Gy} / \mathrm{min}$.).

\section{Discussion}

In order to achieve the best favorable tradeoff between tumor control and treatment-related toxicity, the radiation oncologist, following the most up-to-date guidelines, indicates the number of fractions in which to deliver the maximum possible dose of IR. The new linear accelerator are able to treat patients reaching very high doses delivered with high or ultra-high-dose-rate thus reducing patients' exposure time to IR and potentially inducing less toxicity (Durante et al. 2018). Notably, whether several dose-escalation studies are continuously performed, no sufficient evidences have been collected on the role of the dose-rate. On this regards, some investigators suggest the use of high-dose-rate (HDR) whilst others claim the highest efficiency of low-dose-rate (LDR) (Hall 1972; Steel et al. 1987; Williams et al. 2008; Ling et al. 2010; Terashima et al. 2017; Matsuya et al. 2018). The experiments herein performed show that modulating the dose-rate differently affected the surviving fraction of epithelial-derived PCa and mesenchymal-derived RMS cancer cell lines suggesting that choosing the right dose-rate could really affect the therapeutic efficiency of IR.

IR induces DSBs directly or by inducing ROS accumulation. DNA damage response of mammalian cells usually involves the activation of checkpoint mechanisms that induce cell cycle arrest that allows cells to have enough time to repair the damaged DNA. Unsuccessful DNA repair leads to cell death or senescence (Hufnagl et al. 2015). In this context, cancer cells can escape IR-induced death and reenter the cell cycle by activating several molecular mechanisms. Herein, despite modulating the dose-rate did not differently induced ROS accumulation, we found that the phosphorylation of $\mathrm{H} 2 \mathrm{AX}(\gamma-\mathrm{H} 2 \mathrm{AX})$, biomarker of DSBs 

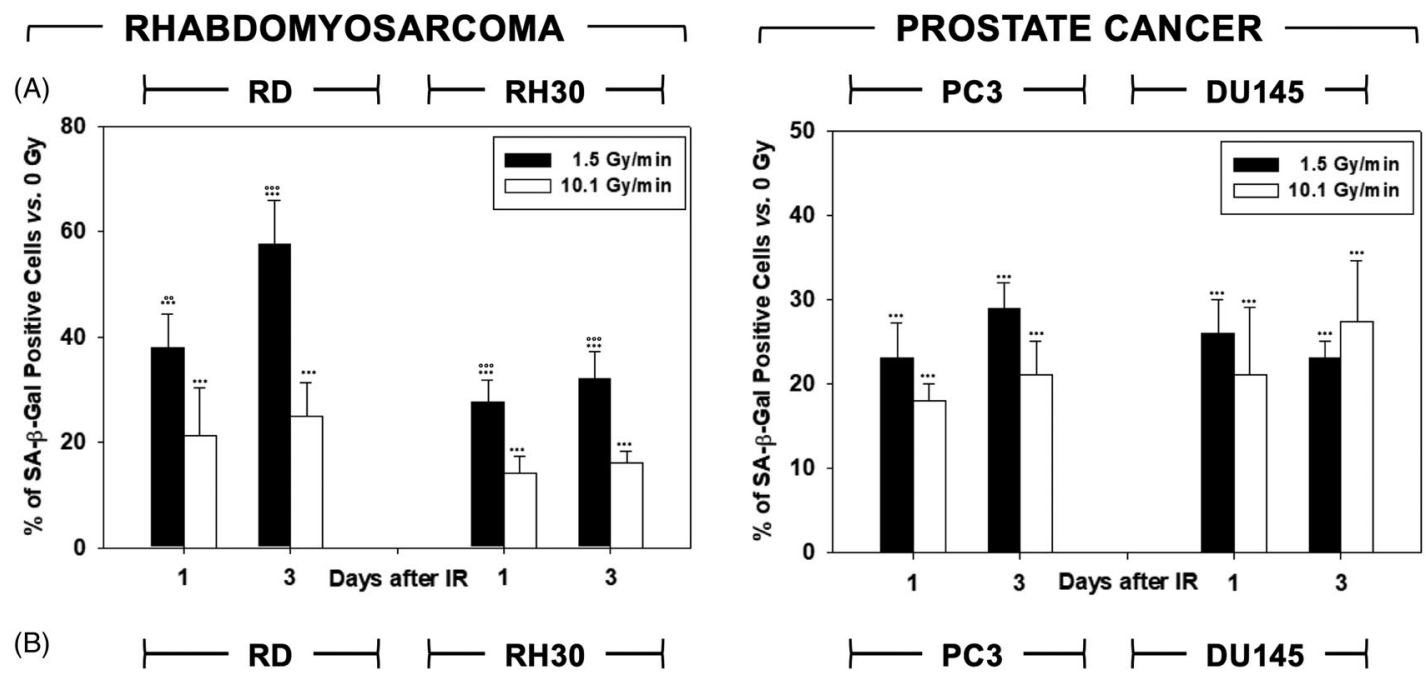

(B)
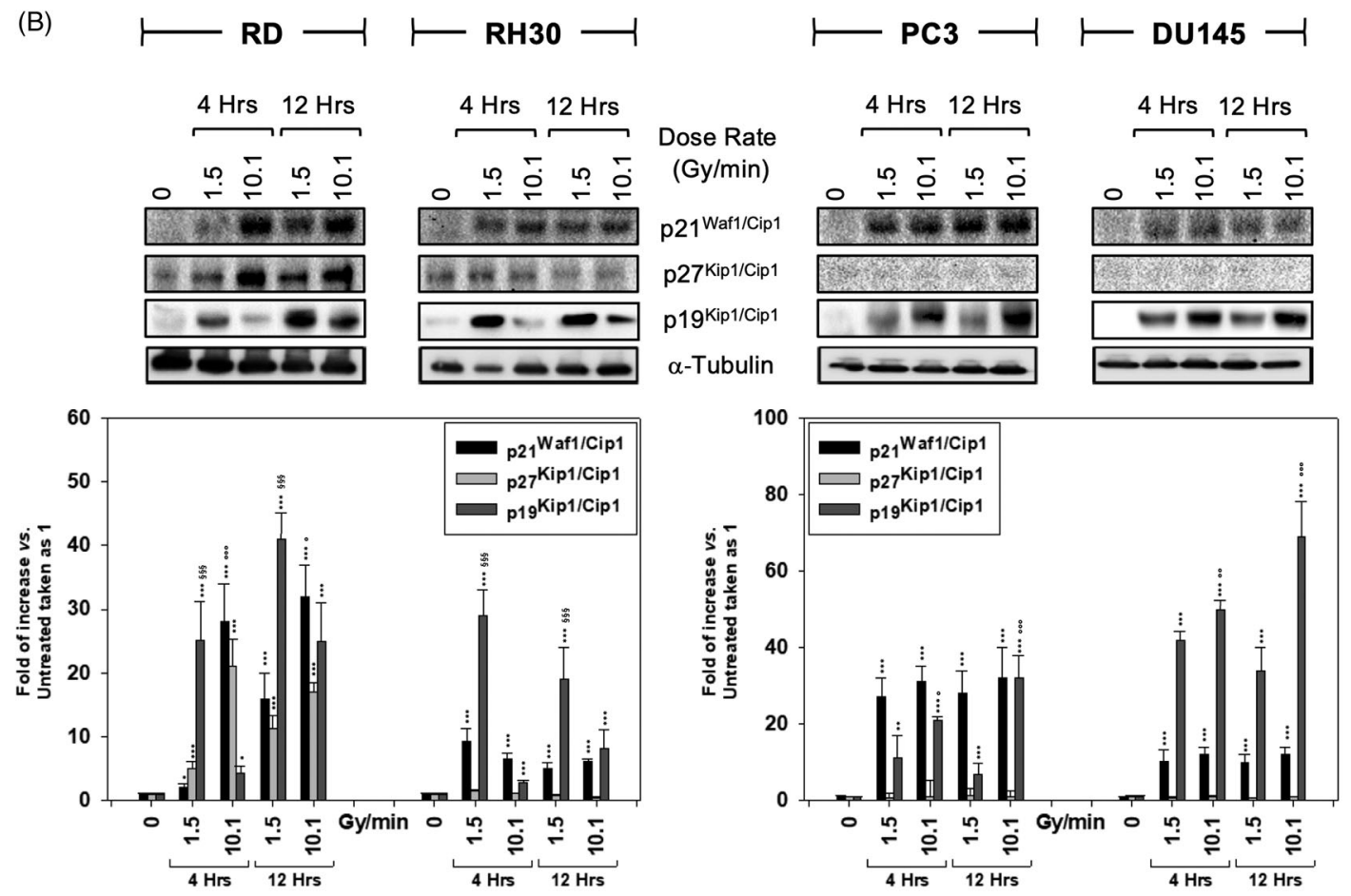

Figure 5. Dose-rate modulation differently induces senescence. Human embryonal (RD), alveolar (RH30) rhabdomyosarcoma and prostate cancer cell lines (PC3 and DU145) were treated on not with a dose of $2 \mathrm{~Gy}$ of radiation, delivered at the dose-rate of 1.5 or $10.1 \mathrm{~Gy} / \mathrm{min}$. (A) Percentage of SA- $\beta$-Gal expressing cells assessed by ELISA were performed at 1 and 3 days after IR. Images shows data from three independent experiments performed in triplicate. (B) Cell lysate was collected 4 and $12 \mathrm{~h}$ after IR; p21 Waf1//ip1, $\mathrm{p} 27^{\mathrm{Kip} 1 / \mathrm{Cip} 1}$ and $\mathrm{p} 19^{\mathrm{Kip} 1 / \mathrm{Cip} 1}$ levels measured by western blotting. Images show representative western blots of three independent experiments; $\alpha$-Tubulin was used as loading control. Densitometric analysis of three independent experiments is reported below the blots; data were expressed as fold of change vs. untreated taken as 1 (0 Gy). Statistical analyses: ${ }^{*} p<.05$, ${ }^{* *} p<.01,{ }^{* * *} p<.001$ vs. untreated, ${ }^{\$ \S \S} p<.001$ vs. $1.5 \mathrm{~Gy} / \mathrm{min},{ }^{\circ} p<.05,{ }^{\circ} p<.01$, ${ }^{\circ 00} p<.001$ vs. $10.1 \mathrm{~Gy} / \mathrm{min}$.

(Kuo and Yang 2008) was more significantly and persistently up-regulated in LDR-RMS and HDR-PCa treated cells. We found that in the presence of the more toxic dose-rate, cancer cells less efficiently activated NHEJ and HR DSBs repair pathways. Notably NHEJ is known to be a error-prone DSBs repair pathway that may convert endogenously induced DSBs to frameshift mutations, potentially responsible of resistance to therapies (Rodgers and McVey 2016; Sishc and Davis 2017; da Silva-Diz et al. 2018). This evidence has several important clinical significances because, depending on the dose-rate used it could be possible to counteract the repair of IR-induced DSBs and prevent the accumulation of radioresistance-inducer mutations. Furthermore, since RT efficacy might be enhanced by using DSBs inhibitors (Biau et al. 2019), the use of a more toxic dose-rate could amplify the effects of these drugs.

Based on the radiobiological principle of redistribution, IR are conventionally delivered with daily fractions. This permit to induce cell cycle arrest in the $\mathrm{G}_{2} / \mathrm{M}$ phase that being the most radiosensitive phase of the cell cycle (Hufnagl et al. 2015) would allow the next fraction to have a greater cytotoxic effect (Hahnfeldt and Hlatky 1996). Daily treating cancer cells with LDR in RMS and HDR in PCa more efficiently increased the percentage of cancer cells arrested in the $G_{2} / M$. Thus choosing the most toxic dose-rate could not only improve the efficacy of a single treatment but amplify the therapeutic efficiency of a fractionated schedule. Moreover, characterizing the type of 

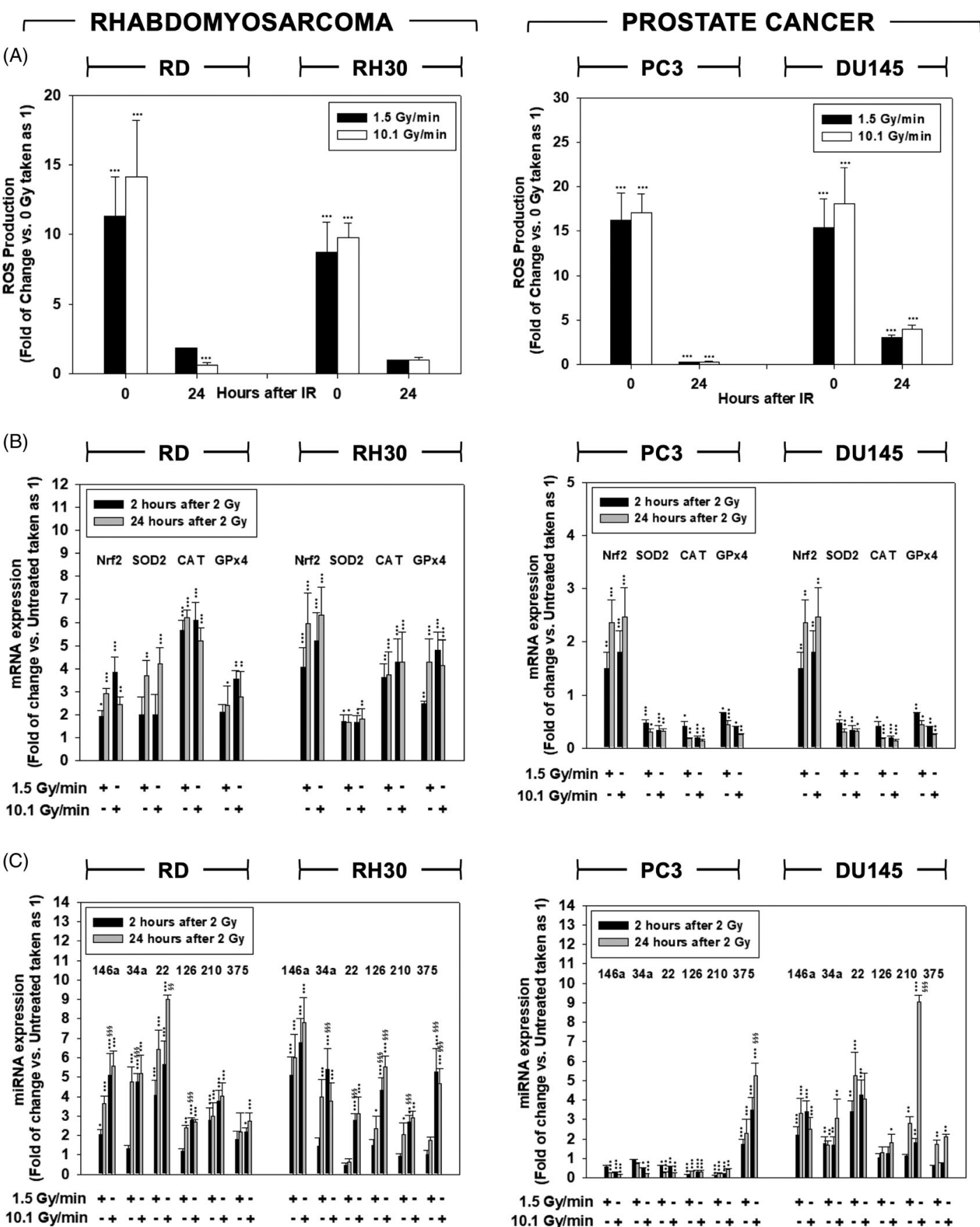

Figure 6. Dose-rate modulation does not affect IR-induced ROS accumulation and anti-oxidant ability of cancer cells. Human embryonal (RD), alveolar (RH30) rhabdomyosarcoma and prostate cancer cell lines (PC3 and DU145) were treated on not with a dose of 2 Gy of radiation, delivered at the dose-rate of 1.5 or $10.1 \mathrm{~Gy} / \mathrm{min}$. (A) Mitochondrial superoxide anion production was assessed by MitoSox Red staining, immediately $(0 \mathrm{~h})$ or $24 \mathrm{~h}$ after IR. Data were expressed as fold of change vs. untreated cells taken as 1 . Images shows data from three independent experiments performed in triplicate. (B) Gene expression of antioxidant enzymes SOD-2, CAT, GPx4, NRF2 and (C) miRNAs miR-146a, -34a, -22, -126, -210 and 375 was investigated by real-time PCR, 2 and $24 \mathrm{~h}$ after IR. The gene expression was referenced to the ratio of the value of interest and basal conditions. Images shows data from three independent experiments performed in triplicate and the value of basal conditions was reported equal to 1 . Statistical analyses: ${ }^{*} p<.05,{ }^{* *} p<.01,{ }^{* * *} p<.001 \mathrm{vs}$. untreated, ${ }^{\S \S} p<.01,{ }^{\S \S} p<.001 \mathrm{vs}$. $1.5 \mathrm{~Gy} / \mathrm{min}$.

cell death induced by IR we found that LDR in RMS and HDR in PCa more efficiently induced apoptosis in RMS and necrosis in $\mathrm{PCa}$ even though caspase-9, -8 and -3 resulted activated in both cell types. IR-induced apoptosis in RMS and necrosis in PCa may depend on the different activation of the caspase- 3 subfamily as already shown in other cell type exposed to IR (Coelho D et al. 2000). Interestingly, both on surviving RMS and PCa cells, IR induced senescence known to create a microenvironment that facilitates neoplastic growth (Tabasso et al. 2019). This could provide a rationale to test the addition of antisenescent drugs, some of which are already available in the clinic, to radiotherapy protocols.

Experiments performed on mouse models show a remarkable sparing of normal tissue and a maintained tumor control level after irradiation at ultra-high doserate (Durante et al. 2018). The evidence herein collected indicate that each tumor has a different sensitivity to 

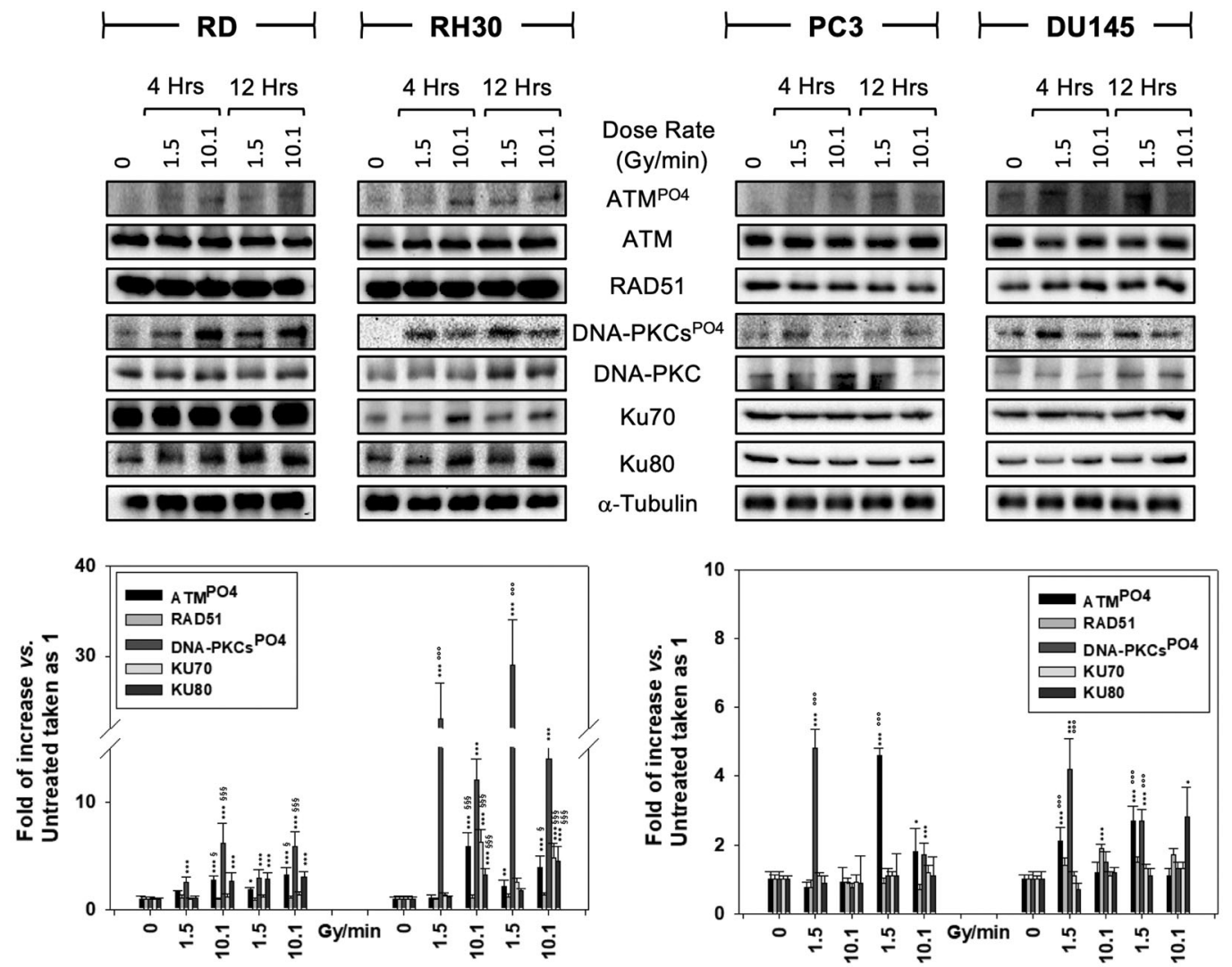

Figure 7. Dose-rate modulation differently affects the activation of DNA double-strand break repair mechanisms of cancer cells. Human embryonal (RD), alveolar $(\mathrm{RH} 30)$ rhabdomyosarcoma and prostate cancer cell lines (PC3 and DU145) were treated on not with a dose of 2 Gy of radiation, delivered at the dose-rate of 1.5 or

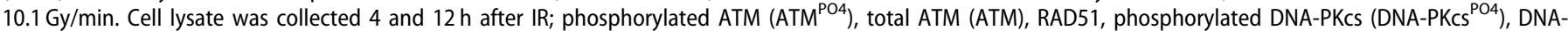

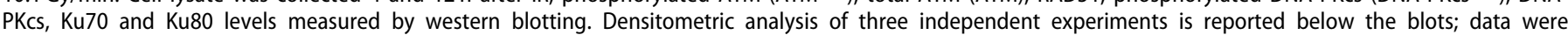

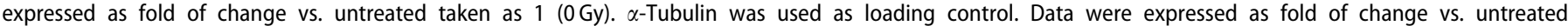
(0 Gy).Statistical analyses: ${ }^{*} p<.05,{ }^{*} * p<.01, * * * p<.001$ vs. untreated, ${ }^{\S \S} p<.01,{ }^{\S \S \S} p<.001 \mathrm{vs} .1 .5 \mathrm{~Gy} / \mathrm{min},{ }^{\circ 00} p<.001 \mathrm{vs} .10 .1 \mathrm{~Gy} / \mathrm{min}$.

different dose rates, thus suggesting that the use of high dose-rates in a non-tumor-specific manner may not guarantee the best result on tumor control. We suppose that the dose-rate should be chosen in a cancer-cell type dependent manner and/or based on the molecular features of any individual patient. This could allow to improve the therapeutic ratio in $\mathrm{RT}$ and to prevent the selection of radioresistant cells responsible for recurrences and metastases.

\section{Acknowledgements}

The authors are grateful to 'FIVA Confcommercio' for supporting part of our work and Francesca Cicchetti to assist us during irradiation experiments.

\section{Compliance with ethical standards}

Ethical approval: Studies on animal models were not performed. This article does not contain any studies with human participants performed by any of the authors.

Informed consent: This article does not contain any studies with human participants performed by any of the authors.

\section{Author contributions}

FP, IP, VDN, IF and ADF planned experiments; CC, SC, PT, SO, SC, and MAM performed experiments; GDE, GP, MT, PDC, AR and AF planned radiation treatments, $\mathrm{LM}, \mathrm{FV}, \mathrm{AF}$ and $\mathrm{RM}$ analyze data; VT and FM wrote the paper.

\section{Disclosure statement}

The authors declare that they have no competing interests.

\section{Notes on contributors}

Francesco Petragnano is a $\mathrm{PhD}$ student at University of L'Aquila, Italy, Laboratory of Pharmacology. He studies the molecular mechanisms of radio-resistance.

Ilaria Pietrantoni is a Postdoc at University of L'Aquila, Italy, Laboratory of Pharmacology. She studies the molecular mechanisms of radio-resistance.

Valentina Di Nisio is a PhD student at University of L'Aquila, Italy, Laboratory of Molecular biology. He studies the molecular mechanisms of radio-resistance.

Irene Fasciani is a Postdoc at University of L'Aquila, Italy, Laboratory of Pharmacology. She studies the molecular mechanisms of radio-resistance. 
Andrea Del Fattore is the director of the Bone Physiopathology Unit genetics and rare diseases research area, Bambino Gesù Children's Hospital. $\mathrm{He}$ is also studying the molecular mechanisms of radio-resistance.

Carlo Capalbo is an Oncologist at University of Rome, Sapienza, Italy. He studies the molecular mechanisms of cancer onset and therapies-resistance.

Sara Cheleschi is a Postdoc at University of Siena, Italy, Laboratory of Rheumatology. She studies the molecular mechanisms regulating cellular response to oxidative stress.

Paolo Tini is a radiation therapist at University of Siena, Italy, Laboratory of Radiobiology. He studies the molecular mechanisms regulating cellular response to radiation.

Simone Orelli is specializing in radiation therapy at University of Rome, Sapienza. He studies the molecular mechanisms of radio-resistance.

Silvia Codenotti is a Postdoc at University of Brescia, Italy, Laboratory of Biochemistry. She studies the molecular mechanisms regulating rhabdomyosarcoma genesis.

Maria Antonietta Mazzei is a full professor of radiology therapist at University of Siena, Italy, Laboratory of Radiobiology. She studies the molecular mechanisms regulating cellular response to radiation.

Giuseppe D'Ermo is a researcher in urology at University of Rome, Sapienza. He studies prostate cancer.

Gaetano Pannitteri is a researcher in cardiology at University of Rome, Sapienza. He studies the molecular mechanisms regulating cellular response to oxidative stress.

Mario Tombolini is an otorinolaringoiatry at University of Rome, Sapienza. He studies the head and neck cancer.

Paola De Cesaris is an associate professor of histology at University of L'Aquila, Italy, Laboratory of Histology. She studies the molecular mechanisms regulating prostate cancer.

Anna Riccioli is an associate professor of histology at University of Siena, Italy, Laboratory of Histology. She studies the molecular mechanisms regulating prostate cancer.

Antonio Filippini is a full professor of histology at University of Siena, Italy, Laboratory of Histology. He studies the molecular mechanisms regulating prostate cancer.

Luisa Milazzo is a researcher at Istituto Superiore di sanità, Rome, Italy. She studies the molecular mechanisms regulating radioresistance.

Francesca Vulcano is a researcher at Istituto Superiore di Sanità, Rome, Italy. She studies the molecular mechanisms regulating radioresistance.

Alessandro Fanzani is an associate professor at University of Brescia, Italy, Laboratory of Biochemistry. He studies the molecular mechanisms regulating rhabdomyosarcoma genesis.

Roberto Maggio a full professor at University of L'Aquila, Italy, Laboratory of Pharmacology. He studies the molecular mechanisms of radio-resistance.

Francesco Marampon is an associate professor of radiation therapy at University of Rome, Sapienza, Italy, Laboratory of Radiobiology. He studies the molecular mechanisms regulating radioresistance.

Vincenzo Tombolini is a full professor of radiation therapy at University of Rome, Sapienza, Italy, Laboratory of Radiobiology. He studies the molecular mechanisms regulating radioresistance.

\section{ORCID}

Valentina Di Nisio (ID http://orcid.org/0000-0002-8435-7925

\section{References}

Ayers D, Baron B, Hunter T. 2015. miRNA influences in NRF2 pathway interactions within cancer models. J Nucleic Acids. 2015: 143636.

Baskar R, Lee KA, Yeo R, Yeoh KW. 2012. Cancer and radiation therapy: current advances and future directions. Int J Med Sci. 3: 193-199.

Biau J, Chautard E, Verrelle P, Dutreix M. 2019. Altering DNA repair to improve radiation therapy: specific and multiple pathway targeting. Front Oncol. 9:1009.

Bjørkøy G, Lamark T, Pankiv S, Øvervatn A, Brech A, Johansen T. 2009. Monitoring autophagic degradation of p62/SQSTM1. Meth Enzymol. 452:181-197.

Cheleschi S, De Palma A, Pascarelli NA, Giordano N, Galeazzi M, Tenti S, Fioravanti A. 2017. Could oxidative stress regulate the expression of MicroRNA-146a and MicroRNA-34a in human osteoarthritic chondrocyte cultures? Int J Mol Sci. 18:12

Cheleschi S, Giordano N, Volpi N, Tenti S, Gallo I, Di Meglio M, Giannotti S, Fioravanti A. 2018. A complex relationship between visfatin and resistin and microRNA: an in vitro study on human chondrocyte cultures. Int J Mol Sci. 19:12.

Ciccarelli C, Di Rocco A, Gravina GL, Mauro A, Festuccia C, Del Fattore A, Berardinelli P, De Felice F, Musio D, Bouché M, et al 2018. Disruption of MEK/ERK/c-Myc signaling radiosensitizes prostate cancer cells in vitro and in vivo. J Cancer Res Clin Oncol. 144: 1685-1699.

Ciccarelli C, Vulcano F, Milazzo L, Gravina GL, Marampon F, Macioce G, Giampaolo A, Tombolini V, Di Paolo V, Hassan HJ, et al. 2016 Key role of MEK/ERK pathway in sustaining tumorigenicity and in vitro radioresistance of embryonal rhabdomyosarcoma stem-like cell population. Mol Cancer. 20:15-16.

Ciccarese F, Ciminale V. 2017. Escaping death: mitochondrial redox homeostasis in cancer cells. Front Oncol. 7:117.

Coelho D, Holl V, Weltin D, Lacornerie T, Magnenet P, Dufour P, Bischoff P. 2000. Caspase-3-like activity determines the type of cell death following ionizing radiation in MOLT-4 human leukaemia cells. Br J Cancer. 83:642-649.

Cortese F, Klokov D, Osipov A, Stefaniak J, Moskalev A, Schastnaya J, Cantor C, Aliper A, Mamoshina P, Ushakov I, et al. 2018. Vive la radiorésistance!: converging research in radiobiology and biogerontology to enhance human radioresistance for deep space exploration and colonization. Oncotarget. 18:14692-14722.

da Silva-Diz V, Lorenzo-Sanz L, Bernat-Peguera A, Lopez-Cerda M, Muñoz P. 2018. Cancer cell plasticity: impact on tumor progression and therapy response. Semin Cancer Biol. 53:48-58.

De Palma A, Cheleschi S, Pascarelli NA, Tenti S, Galeazzi M, Fioravanti A. 2017. Do MicroRNAs have a key epigenetic role in osteoarthritis and in mechanotransduction? Clin Exp Rheumatol. 35 518-526.

Dimri GP, Lee X, Basile G, Acosta M, Scott G, Roskelley C, Medrano EE, Linskens M, Rubelj I, Pereira-Smith O. 1995. A biomarker that identifies senescent human cells in culture and in aging skin in vivo. Proc Natl Acad Sci USA. 92:9363-9367.

Durante M, Bräuer-Krisch E, Hill M. 2018. Faster and safer? FLASH ultra-high dose rate in radiotherapy. Br J Radiol. 91:20170628.

Eriksson D, Stigbrand T. 2010. Radiation-induced cell death mechanisms. Tumor Biol. 31:363-372.

Gravina GL, Festuccia C, Popov VM, Di Rocco A, Colapietro A, Sanità P, Monache SD, Musio D, De Felice F, Di Cesare E, et al. 2016. c-Myc sustains transformed phenotype and promotes radioresistance of embryonal rhabdomyosarcoma cell lines. Radiat Res. 185: $411-422$ 
Gravina GL, Mancini A, Marampon F, Colapietro A, Delle Monache S, Sferra R, Vitale F, Richardson PJ, Patient L, Burbidge S, et al. 2017. The brain-penetrating CXCR4 antagonist, PRX177561, increases the antitumor effects of bevacizumab and sunitinib in preclinical models of human glioblastoma. J Hematol Oncol. 10:5.

Gravina GL, Mancini A, Ranieri G, Di Pasquale B, Marampon F, Di Clemente L, Ricevuto E, Festuccia C. 2013. Phenotypic characterization of human prostatic stromal cells in primary cultures derived from human tissue samples. Int J Oncol. 42:2116-2122.

Gravina GL, Marampon F, Sherris D, Vittorini F, Di Cesare E, Tombolini V, Lenzi A, Jannini EA, Festuccia C. 2014. Torc1/Torc2 inhibitor, Palomid 529, enhances radiation response modulating CRM1-mediated survivin function and delaying DNA repair in prostate cancer models. Prostate. 74:852-868.

Guo Y, Li P, Gao L, Zhang J, Yang Z, Bledsoe G, Chang E, Chao L, Chao J. 2017. Kallistatin reduces vascular senescence and aging by regulating microRNA-34a-SIRT1 pathway. Aging Cell. 16:837-846.

Hahnfeldt P, Hlatky L. 1996. Resensitization due to redistribution of cells in the phases of the cell cycle during arbitrary radiation protocols. Radiat Res. 145:134-143.

Hall EJ. 1972. Radiation dose-rate: a factor of importance in radiobiology and radiotherapy. Br J Radiol. 45:81-97.

Hufnagl A, Herr L, Friedrich T, Durante M, Taucher-Scholz G, Scholz M. 2015. The link between cell-cycle dependent radiosensitivity and repair pathways: a model based on the local, sister-chromatid conformation dependent switch between NHEJ and HR. DNA Repair (Amst). 27:28-39.

Kabeya Y, Mizushima N, Ueno T, Yamamoto A, Kirisako T, Noda T, Kominami E, Ohsumi Y, Yoshimori T. 2000. LC3, a mammalian homologue of yeast Apg8p, is localized in autophagosome membranes after processing. Embo J. 19:5720-5728.

Kuo LJ, Yang LX. 2008. Gamma-H2AX - a novel biomarker for DNA double-strand breaks. In Vivo. 22:305-309.

Ling CC, Gerweck LE, Zaider M, Yorke E. 2010. Dose-rate effects in external beam radiotherapy redux. Radiother Oncol. 95:261-268.

Marampon F, Codenotti S, Megiorni F, Del Fattore A, Camero S, Gravina GL, Festuccia C, Musio D, De Felice F, Nardone V, et al. 2019. NRF2 orchestrates the redox regulation induced by radiation therapy, sustaining embryonal and alveolar rhabdomyosarcoma cells radioresistance. J Cancer Res Clin Oncol. 145:881-893.

Marampon F, Gravina GL, Di Rocco A, Bonfili P, Di Staso M, Fardella C, Polidoro L, Ciccarelli C, Festuccia C, Popov VM, et al. 2011. MEK/ERK inhibitor U0126 increases the radiosensitivity of rhabdomyosarcoma cells in vitro and in vivo by downregulating growth and DNA repair signals. Mol Cancer Ther. 10:159-168.

Marampon F, Gravina GL, Festuccia C, Popov VM, Colapietro EA, Sanità P, Musio D, De Felice F, Lenzi A, Jannini EA, et al. 2016. Vitamin D protects endothelial cells from irradiation-induced senescence and apoptosis by modulating MAPK/SirT1 axis. J Endocrinol Invest. 39:411-422.

Marampon F, Gravina GL, Ju X, Vetuschi A, Sferra R, Casimiro MC, Pompili S, Festuccia C, Colapietro A, Gaudio E, et al. 2016. Cyclin D1 silencing suppresses tumorigenicity, impairs DNA double strand break repair and thus radiosensitizes androgen-independent prostate cancer cells to DNA damage. Oncotarget. 7:64526.

Marampon F, Gravina GL, Popov VM, Scarsella L, Festuccia C, La Verghetta ME, Parente S, Cerasani M, Bruera G, Ficorella C, et al.
2014. Close correlation between MEK/ERK and Aurora-B signaling pathways in sustaining tumorigenic potential and radioresistance of gynecological cancer cell lines. Int J Oncol. 44:285-294.

Matsuya Y, McMahon SJ, Tsutsumi K, Sasaki K, Okuyama G, Yoshii Y, Mori R, Oikawa J, Prise KM, Date H. 2018. Investigation of dose-rate effects and cell-cycle distribution under protracted exposure to ionizing radiation for various dose-rates. Sci Rep. 8:8287.

Morgan MA, Lawrence TS. 2015. Molecular pathways: overcoming radiation resistance by targeting DNA damage response pathways. Clin Cancer Res. 13:2898-2904.

Nguyen T, Nioi P, Pickett CB. 2009. The Nrf2-antioxidant response element signaling pathway and its activation by oxidative stress. J Biol Chem. 284:13291-13295.

Ou J, Kou L, Liang L, Tang C. 2017. MiR-375 attenuates injury of cerebral ischemia/reperfusion via targetting Ctgf. Biosci Rep. 22:37.

Qu X, Wang N, Cheng W, Xue Y, Chen W, Qi M. 2019. MicroRNA146a protects against intracerebral hemorrhage by inhibiting inflammation and oxidative stress. Exp Ther Med. 18:3920-3928.

Rodgers K, McVey M. 2016. Error-prone repair of DNA double-strand breaks. J Cell Physiol. 231:15-24.

Rojo de la Vega M, Chapman E, Zhang DD. 2018. NRF2 and the hallmarks of cancer. Cancer Cell. 34:21-43.

Sishc BJ, Davis AJ. 2017. The role of the core non-homologous end joining factors in carcinogenesis and cancer. Cancers (Basel). 9:81.

Srinivas US, Tan BWQ, Vellayappan BA, Jeyasekharan AD. 2018. ROS and the DNA damage response in cancer. Redox Biol. 21:101084.

Steel GG, Deacon JM, Duchesne GM, Horwich A, Kelland LR, Peacock JH. 1987. The dose-rate effect in human tumour cells. Radiother Oncol. 4:299-310.

Sun W, Zhao L, Song X, Zhang J, Xing Y, Liu N, Yan Y, Li Z, Lu Y, $\mathrm{Wu}$ J, et al. 2017. MicroRNA-210 modulates the cellular energy metabolism shift during $\mathrm{H} 2 \mathrm{O} 2$-induced oxidative stress by repressing ISCU in H9c2 cardiomyocytes. Cell Physiol Biochem. 43:383-394.

Sutera P, Clump DA, Kalash R, D'Ambrosio D, Mihai A, Wang $\mathrm{H}$, Petro DP, Burton SA, Heron DE. 2019. Initial results of a multicenter phase 2 trial of stereotactic ablative radiation therapy for oligometastatic cancer. Int J Radiat Oncol Biol Phys. 103:116-122.

Tabasso AFS, Jones DJL, Jones GDD, Macip S. 2019. Radiotherapyinduced senescence and its effects on responses to treatment. Clin Oncol (R Coll Radiol). 31:283-289.

Tang Q, Len Q, Liu Z, Wang W. 2018. Overexpression of miR-22 attenuates oxidative stress injury in diabetic cardiomyopathy via Sirt 1. Cardiovasc Ther. 36:e12318.

Terashima S, Hosokawa Y, Tsuruga E, Mariya Y, Nakamura T. 2017. Impact of time interval and dose rate on cell survival following lowdose fractionated exposures. J Radiat Res. 58:782-790.

Wang W, Zheng Y, Wang M, Yan M, Jiang J, Li Z. 2019. Exosomes derived miR-126 attenuates oxidative stress and apoptosis from ischemia and reperfusion injury by targeting ERRFI1. Gene. 690: $75-80$.

Williams JR, Zhang Y, Zhou H, Gridley DS, Koch CJ, Slater JM, Little JB. 2008. Overview of radiosensitivity of human tumor cells to lowdose-rate irradiation. Int J Radiat Oncol Biol Phys. 72:909-917.

Zimmermann M, Meyer N. 2011. Annexin V/7-AAD staining in keratinocytes. Methods Mol Biol. 740:57-63. 